\title{
"Conflict of Goals" as a Barrier for Effective Use of Visual Models in Primary Math Education
}

\author{
(D)Maria Urban ${ }^{1}$ Dr. paed.; (DDaina Vasilevska ${ }^{2}$ Dr. sc. admin. \\ Belarusian State Pedagogical University, Belarus ${ }^{1}$; Liepaja University, Latvia ${ }^{2}$ \\ maria.urban62@gmail.com ${ }^{1}$; daina.vasilevska@gmail.com²
}

\begin{abstract}
The formation of the ability to solve non-trivial life problems is one of the tasks of school education in the context of achieving sustainable development goals. In the process of teaching mathematics, one of the most effective ways to find solutions to problems is modelling - a teaching method that not only helps students to consciously assimilate mathematical content, but also forms the basis for selfstudy throughout life. Visual models, which reflect the essential characteristics of mathematical concepts by pictorial means, play a special role in the process of initial teaching of mathematics. Teachers can use active and passive techniques for working with visual models in mathematics lessons, which differ in the degree of children's participation in building a visual model. The main goal of this article is to identify which techniques teachers prefer working with visual models in practice in mathematics lessons. To achieve this goal, the questionnaire method, the multi-criteria assessment method, and the moderation method were applied. This article presents the results of a study devoted to identifying teachers' preferred methods of working with visual models when conducting mathematics lessons, identifying their theoretical ideas about the value of each group of techniques, as well as establishing the reasons for the revealed discrepancy between the practical preferences of teachers and their theoretical ideas.
\end{abstract}

Keywords: visualization in mathematics education, visual models, teaching techniques, primary mathematics education.

\section{Introduction}

Topical global problems of the world are associated with such phenomena as epidemics, environmental pollution, climate change, natural disasters and man-made accidents. Solving these problems requires a multidisciplinary approach, which consists of a synergy of practice and knowledge, social, natural and engineering sciences, based on mathematics (Clark, Levin, 2010). Learning for sustainable development requires teachers to be open-minded and flexible, and ready to accept each new perspective. Education for sustainable development should take into account that the learning process should be student-centred (based on the student's experience and questions), processes (emphasis on patterns), actions (to develop the ability to act), assess (to develop critical thinking and the ability to solve non-standard problems reality), society (to involve students in identifying and solving real problems) and complex problem solving (including economic, environmental and social aspects) (Vasilevska, Geske, 2020). One of the most important tasks facing the teacher is the development of an independent logic of thinking, which would allow students to build inferences, provide evidence, statements that are logically related to each other, draw conclusions, justify their judgments, and, ultimately, independently acquire knowledge. Mathematics is exactly the subject where this can be largely implemented. One of the most effective ways to find a solution to a problem that is formed in the process of studying mathematics is modelling. Modelling as a method of teaching mathematics contributes to both the assimilation of subject content and the general mental development of students, equipping them with one of the most effective tools for self-study throughout life (Stillman et al., 2016; Doğan et al., 2019).

The use of modelling as a method of teaching mathematics involves ensuring its compliance with the process of solving a real problem by means of mathematics in scientific cognition ("cycle of mathematics") proposed by J. De Lange: real-word problem - mathematical problem - mathematical solution - real solution (De Lange, 2006). An important addition to this cycle, considering the specifics of teaching primary school students, is the concept of a "real model" introduced by W. Blum: the author believes that between a real problem and a mathematical model there is a real model, which is a simplified reflection of the essential features of the analysed situations in visual presentation. Only then can the real model be more correctly and consciously transformed into a mathematical model (Blum, Leiß, 2007). 
In this regard, visualization of the studied abstract concepts is of particular importance in the process of studying mathematics. This idea receives wide coverage in studies of the late XX - early XXI century, and currently the ability of a student to represent mathematical ideas using various (including visual) means of representation is recognized in a number of studies as an important component of mathematical competence (Vorobjovs, 2020). In modern education, two directions of research on the problem of visualization in teaching mathematics are developing.

The first direction is associated with the use of traditional visualization tools to create visual images of mathematical concepts. According to G.A. Goldin, the images created by students that model the concepts of numbers, figures and relationships, not only have a positive effect on the assimilation of mathematical content, but also allow to form in students already in elementary school the ability to representation fluency - the presentation of information by various means and the transition from one type of representation to another (Goldin, 2008; Cartwright, 2020). The ability to understand information presented in different languages - mathematical symbols, natural language and the language of images (diagrams, schemes, graphs) L.D. English calls the most important social skill of a person, the role of which in modern society is constantly growing. At the same time, the author substantiates the need for teaching modelling at an early school age (Asempapa, 2015; English, 2015; Helmane, 2017).

The second direction of research in the field of visualization of teaching mathematics is associated with the development of interactive computer models that allow to study of mathematical concepts in dynamics. The results obtained in this direction are based on the principles of designing applets for educational problems developed in the studies by C. Wieman (Wieman, Perkins, 2005). At present, the use of visual computer models in teaching mathematics goes beyond the narrow pedagogical task of helping students memorize educational materials and turns into a tool for educational research and experimentation (Kadunz, Yerushalmy, 2015).

However, despite the importance of the "computer" the direction of visual modelling in mathematics education for primary school students, the construction of visual models using traditional teaching aids (handouts, paper, pencil, blackboard, chalk) continues to be a more valuable and necessary part of learning, since it relies on manipulative activity and visual thinking of students of this age group (Urban, Murauyova, Gadzaova, 2017; Haylock, Cockburn, 2017; Lehrer, Schauble, 2019).

In the process of using visual models in mathematics lessons, teachers can rely on a greater or lesser degree of student independence. For example, a teacher can use passive techniques for working with models - showing students a scheme for a textual task to explain how to solve it, without asking students to build this model on their own. The teacher can also use active techniques for working with models, inviting students to independently build a visual model in whole or in part.

In the modern scientific and methodological discourse, the need for students' vigorous activity (both mental and practical) in the process of acquiring knowledge is considered as one of the basic principles of effective teaching. However, the question remains about to what extent teachers implement this principle in their daily practice, what methods of working with visual models they prefer.

The purpose of this article: 1) to identify which methods of working with visual models are preferred by teachers in practice in mathematics lessons; 2) to determine whether the practical choices of teachers correspond to their theoretical ideas about the value of each of the groups of techniques; 3 ) on the basis of the data obtained, to establish the reasons for the coincidence or difference between the practical and theoretical preferences of teachers.

\section{Methodology}

To achieve this goal, based on the performed theoretical analysis and generalization of its results, the questionnaire method was applied, with the help of which the preferred methods of using visual models in their practice of teaching mathematics were identified. At the next stage of the study, using the method of multi-criteria assessment, the opinion of teachers about the didactic value of active and passive methods of using visual models was revealed. To establish the reasons for the discrepancy between the practical choices of teachers and their theoretical ideas revealed in the course of the study, the method of moderation was used. 
The study was conducted based on the Faculty of Primary Education of the Belarusian State Pedagogical University in 2020 .

\section{Results and discussion}

\section{The first stage of the study.}

In January 2020, 131 primary school teachers of part-time higher education at the Belarusian State Pedagogical University were asked to answer the questionnaire. The purpose of the survey was to identify the preferred methods of using models in mathematics lessons by teachers. Teachers were asked to evaluate their practice of using visual models on the example of constructing schematic drawings and pictures for textual tasks, indicating the frequency of using active (students build visual models themselves) and passive (students use the visual model proposed by the teacher) techniques for working with models (Table 1).

Table 1

The frequency of using active and passive techniques for working with models

\begin{tabular}{|l|c|c|c|c|c|}
\hline & Never & $\begin{array}{c}\text { Seldom (no more } \\
\text { than 1 lesson per } \\
\text { week) }\end{array}$ & $\begin{array}{c}\text { Sometimes } \\
(\mathbf{2 - 3} \text { lessons } \\
\text { per week) }\end{array}$ & $\begin{array}{c}\text { Often } \\
\text { (4 lessons per } \\
\text { week) }\end{array}$ & Total \\
\hline Active techniques & 7 & 81 & 39 & 4 & 131 \\
$(5 \%)$ & $(62 \%)$ & 17 & $38 \%)$ & 76 & 131 \\
\hline Passive techniques & 0 & $(13 \%)$ & $(29 \%)$ & $(58 \%)$ & $(100 \%)$ \\
\hline
\end{tabular}

The results obtained indicate that when conducting mathematics lessons, the majority of teachers out of 131 respondents ( 81 people, $62 \%$ ) use active techniques of working with visual models no more than once a week (rarely). Passive techniques for working with visual models, on the contrary, are used most often (76 people, $58 \%$ ). Thus, in mathematics lessons, most teachers prefer to offer a "ready-made" model, explaining with its help the way to solve the problem, and the students themselves are rarely involved in building a visual model.

\section{The second stage of the study.}

Furthermore, in the course of the study, a representative sample of 25 teachers who took part in the survey was formed by the method of random selection. To determine the theoretical understanding of teachers about the value of active and passive methods of working with visual models, the method of multi-criteria assessment was adapted to the specifics of the study (Erdogan, Šaparauskas, Turskis, 2019).

First, a group of teachers, during the discussion, formulated evaluation criteria: the first criterion is the time spent on solving the problem; the second is the students' understanding of the way of solving the problem, the third is the strength of mastering the ability to solve problems, the fourth is the formation of the ability to independently build visual models for solving the problem.

For each criterion, its weight in the overall assessment was determined, after which, during the discussion, an assessment of active and passive methods of working with visual models was given for each of the criteria. The procedure used a five-point school ( 1 point - the minimum value, 5 points - the maximum value). The results of the multi-criteria assessment are presented in Table 2.

Table 2

Multi-criteria assessment of active and passive methods of working with visual models

\begin{tabular}{|l|c|c|c|c|c|}
\hline & $\begin{array}{c}\text { First criterion } \\
\mathbf{0 , 2}\end{array}$ & $\begin{array}{c}\text { Second } \\
\text { criterion } \\
\mathbf{0 , 3}\end{array}$ & $\begin{array}{c}\text { Third } \\
\text { criterion } \\
\mathbf{0 , 3}\end{array}$ & $\begin{array}{c}\text { Fourth } \\
\text { criterion } \\
\mathbf{0 , 2}\end{array}$ & $\begin{array}{c}\text { Weighted } \\
\text { score }\end{array}$ \\
\hline Active techniques & 2 & 5 & 4 & 5 & 4,1 \\
\hline Passive techniques & 4 & 4 & 2 & 1 & 2,8 \\
\hline
\end{tabular}

The results obtained showed a discrepancy between the practical choices of teachers and their theoretical concepts: active techniques of working with visual models were recognized as more valuable (weighted score 4,1 ). Passive techniques were rated significantly lower by teachers (weighted score 2,8 ). Thus, a problem 
was identified: knowing that active techniques are more effective for teaching mathematics, teachers continue to use mainly passive techniques for working with visual models in the classroom. Therefore, at the next stage of the study, it was important to establish the reasons for the identified discrepancy.

\section{The third stage of the study.}

To establish the reasons for the identified discrepancy, the moderation method was applied, which is a structured search for the causes of the problem and ways to solve it in teamwork (Legewie, Böhm, 2015). A group of 25 teachers who worked at the previous stage of the study formulated answers to the question "Why do many teachers prefer to use passive techniques for working with visual models in mathematics lessons, despite the fact that they understand the value of active techniques?" Each teacher recorded three answers to this question on cards, after which all answer cards were analysed and grouped, as a result of which several clusters of causes were identified. Table 3 shows the clusters with the largest number of cards.

Table 3

\section{Clusters of causes}

\begin{tabular}{|l|l|l|}
\hline No & \multicolumn{1}{|c|}{ Cluster } & \multicolumn{1}{c|}{ Description } \\
\hline 1 & $\begin{array}{l}\text { Saving time during the } \\
\text { lesson }\end{array}$ & $\begin{array}{l}\text { The teacher spends less time explaining how to solve the problem using passive } \\
\text { techniques of working with the visual model. As a result, he can complete a } \\
\text { larger number of tasks with students, which is subjectively assessed as an } \\
\text { effectively conducted mathematics lesson }\end{array}$ \\
\hline 2 & $\begin{array}{l}\text { Acceptable level of } \\
\text { understanding by the } \\
\text { end of the lesson }\end{array}$ & $\begin{array}{l}\text { Students at the end of the lesson, which explains how to solve a problem, are } \\
\text { able to solve a similar problem, acting on the model of the teacher. Therefore, } \\
\text { it is assessed by the teacher as a quickly achieved learning outcome }\end{array}$ \\
\hline 3 & $\begin{array}{l}\text { Lack of motivation to } \\
\text { achieve a delayed } \\
\text { result }\end{array}$ & $\begin{array}{l}\text { The strength of mastering the ability to solve problems should be checked after } \\
\text { a certain time interval, not less than after 2-3 weeks. Therefore, skill strength is } \\
\text { perceived as an important, but not the most urgent task of a math lesson }\end{array}$ \\
\hline 4 & $\begin{array}{l}\text { Lack of motivation to } \\
\text { achieve hard-to- } \\
\text { measure results }\end{array}$ & $\begin{array}{l}\text { Diagnostics of cognitive skills, including the ability to build visual models, } \\
\text { have not yet been brought to the technological level. As a result, it is easier for } \\
\text { a teacher to evaluate the ability to solve a problem than the ability to build a } \\
\text { visual model for it }\end{array}$ \\
\hline 5 & $\begin{array}{l}\text { Insufficient } \\
\text { methodological } \\
\text { preparation of the } \\
\text { teacher }\end{array}$ & $\begin{array}{l}\text { It is easier for a teacher to build a visual model for a task on the blackboard than } \\
\text { to teach students to build it on their own. In addition, the methodology for the } \\
\text { formation of the ability to model in students is still in the process of becoming }\end{array}$ \\
\hline
\end{tabular}

The analysis of the reasons identified allowed us to conclude that the goals facing the teacher in the mathematics lesson are planned results with different time horizons. For example, time savings and, as a consequence, a greater volume of completed tasks, as well as the ability to solve a similar problem by the sample are short-term goals that can be achieved by the end of the lesson. At the same time, the strength of students' mastery of the ability to solve problems and their ability to build visual models on their own are long-term goals that are not considered by the teacher as urgent. In addition, the achievement of these goals is often difficult to measure and not fully developed: in particular, in modern sources there are only separate publications on the problems of diagnosing the ability to model in students (Urban, Smoleusova, 2020).

As a result of the discussion with a group of teachers, the conclusion was formulated: if the teacher in the lesson simultaneously faces goals with different time horizons (there is a "conflict of goals"), then the choice is made in favour of short-term goals. According to teachers, this is the main barrier in choosing more effective techniques for working with visual models in a math lesson. The data obtained can be correlated with the problem of procrastination, well-known in the field of personality psychology, one of the manifestations of which is a person's preference for short-term activities, the implementation of which immediately leads to the expected result (Steel, 2007). In further work, it is planned to investigate the issue of the reasons for such pedagogical procrastination and ways to overcome it. 


\section{Conclusions}

The use of visual models in elementary mathematics education is an effective teaching tool that helps children both in mastering mathematical content and in developing their cognitive independence for a full life in society. In the course of the study, the following results were obtained:

- teachers prefer to use passive techniques of working with visual models in mathematics lessons, the peculiarity of which is to present to students the models built by the teacher; at the same time, the students themselves only observe the work of the teacher, but do not get the experience of independently building a visual model;

- the practical preferences of teachers do not correspond to their theoretical ideas: teachers understand the high pedagogical value of active techniques for working with visual models, when students actively participate in their construction, but use these techniques in mathematics lessons much less often than passive techniques;

- one of the main reasons for the revealed discrepancy between practical preferences and theoretical ideas of teachers is a "conflict of goals" with different time horizons: in a mathematics lesson, teachers often choose short-term goals that can be achieved by the end of the lesson; at the same time, the long-term goals associated with the formation of general approaches to solving the problem and modelling skills of students are perceived by teachers as less urgent and relevant (the phenomenon of pedagogical procrastination).

Primary school is the optimal period for the formation of abstract-logical and conceptual forms of thinking, since the lack of formation of these types of thinking leads to persistent academic failure. Generalized and specific knowledge obtained as a result of spontaneously forming thought processes are ordered much weaker and coexist in the student's understanding, instead of forming into a clearly structured system. The results of the study confirm that the method of teaching mathematics using educational modelling is effective and significantly changes the attitude of students to the educational process. The methodological significance of the use of educational modelling lies in the fact that the student, solving a task by using the method of modelling, argues like a researcher. Therefore, the role of modelling in teaching any academic discipline is high.

\section{Bibliography}

1. Asempapa R.S. (2015). Mathematical Modelling: Essential for Elementary and Middle School Students. Journal of Mathematics Education, Spring, 8(1), 16-29. Retrieved from http://educationforatoz.com/images/Asempapa_2015-Spring_.pdf

2. Blum W., Leiß D. (2007). How do students and teachers deal with modelling problems? In C. Haines, P. Galbraith, W. Blum, S. Khan (Eds.), The Proceeding of International conference Mathematical modelling: education, engineering and economics (ICTMA 12): Education, 12. Chichester: Woodhead Publishing. 222-231.doi: 10.1533/9780857099419.5.221

3. Cartwright K. (2020). Analyzing students' communication and representation of mathematical fluency during group tasks. The Journal of Mathematical Behavior, 60. doi: 10.1016/j.jmathb.2020.100821

4. De Lange J. (2006). Mathematical literacy for living from OECD-PISA perspective. Tsukuba Journal of Educational Study in Mathematics, 25, 13-35. Retrieved from: http://www.human.tsukuba.ac.jp/ mathedu/2503.pdf

5. Doğan M., Gürbüz R., Çavuş Erdem Z., Şahin S. (2019). Using mathematical modelling for integrating STEM disciplines: a theoretical framework. Turkish Journal of Computer and Mathematics Education, 10(3), 628-653. doi: 10.16949/turkbilmat.502007

6. English L.D. (2015). Learning through modelling in the primary years. In L.H. Lee, D.K.E. Ng (Eds.), Mathematical modelling: from theory to practice. Singapore: Nanyang Technological University, 99-124. doi: 10.1142/9789814546928_0007

7. Erdogan S.A., Šaparauskas J., Turskis Z. (2019). A Multi-Criteria Decision-Making Model to Choose the Best Option for Sustainable Construction Management. Sustainability 11(8), 2239. doi: 10.3390/SU11082239

8. Goldin G.A. (2008). Representation in mathematical learning and problem solving. In L.D. English, D. Kirshner (Eds.), Handbook of international research in mathematics education. London: Rotledge 197-218. Retrieved from https://www.routledgehandbooks.com/doi/10.4324/9780203930236.ch9 
9. Haylock D., Cockburn A.D. (2017). Understanding mathematics for young children: a guide for teachers of children 3-7 ( ${ }^{\text {th }}$ ed.). Los Angeles: Sage Publications.

10. Helmane I. (2017). Thematic Approach and Mathematics Textbooks in Primary School. In V. Dislere (Ed.), The Proceedings of the International Scientific Conference Rural Environment. Education. Personality (REEP), 10. Jelgava: LLU, 70-77. Retrieved from https://llufb.llu.lv/conference/REEP/2017/Latvia-Univ-Agricult-REEP-2017_proceedings-70-77.pdf

11. Kadunz G., Yerushalmy M. (2015). Visualization in the Teaching and Learning of Mathematics. In: Cho S. (Eds) The Proceedings of the International Congress on Mathematical Education, 12. Cham: Springer, 463-467. doi: 10.1007/978-3-319-12688-3_41

12. Legewie H., Böhm B. (2015). Moderation of Teamwork: Basics and Techniques. Retrieved from https://www.ztg.tu-berlin.de/download/legewie/Mod-engl-kurz.pdf

13. Lehrer R., Schauble L. (2019). Learning to play the modelling game, In A. Upmeier zu Belzen, D. Krüger, J. van Driel (Eds.), Towards a Competence-Based View on Models and Modeling in Science Education. Models and Modeling in Science Education, 12. Cham: Springer, 221-236. doi: 10.1007/978-3-030-30255-9_13

14. Levin S.A., Clark W.S. (Eds.). (2010). Toward a Science of Sustainability. John F. Kennedy School of Government, Harvard University. Retrieved from https://dash.harvard.edu/handle/1/9774654

15. Steel P. (2007). The nature of procrastination: A meta-analytic and theoretical review of quintessential self-regulatory failure. Psychological Bulletin, 133(1), 65-94. doi: 10.1037/00332909.133.1.65

16. Stillman G., Brown J., Galbraith P., Ng K.E.D. (2016). Research into Mathematical Applications and Modelling. In K. Makar, S. Dole, J. Visnovska, M. Goos, A. Bennison, K. Fry (Eds.) Research in Mathematics Education in Australasia 2012-2015. Singapore: Springer, 281-304. doi: 10.1007/978-981-10-1419-2_14

17. Urban M., Murauyova H., Gadzaova S. (2017). Didactic principles of visualization of mathematical concepts in primary education. Pedagogika, 127(3), 70-86. doi: 10.15823/p.2017.40

18. Urban M., Smoleusova T. (2020). Characteristics and sub-skills of mathematical modelling in the mathematics curriculum for primary schools. Science for Education Today, 10(4), 139-155. doi: 10.15293/2658-6762.2004.09 (in Russian, abstract in English).

19. Vasilevska D., Geske A. (2020). Competency-Based Approach to Educational Content for Sustainable Development in Latvia. In V. Dislere (Ed.), The Proceedings of the International Scientific Conference Rural Environment. Education. Personality (REEP), 13. Jelgava: Latvia University of Life Sciences and Technologies, 340-347. doi: 10.22616/REEP.2020.041

20. Vorobjovs A. (2020). How to Measure Adolescents' Mathematical Competence, In V. Dislere (Ed.), The Proceedings of the International Scientific Conference Rural Environment. Education. Personality (REEP), 13. Jelgava: Latvia University of Life Sciences and Technologies, 185-190. doi: 10.22616/REEP.2020.022

21. Wieman C., Perkins K. (2005). Transforming physics education. Physics Today, 58(11), 36-41. doi: 10.1063/1.2155756 